\title{
Development of Adults' Autonomous English Learning Experience in Blended Learning Environment: Transformation of Action
}

\author{
Ināra Bojāre Mg.paed. \\ Daugavpils University, Latvia \\ inara.bojare@inbox.lv
}

\begin{abstract}
Holistic approach is essential in postmodern situation when the educational process is aimed at facilitation the development of a personality capable to autonomous learning in blended learning environment as preparing for self-organised learning process in virtual learning environment in the context of sustainable development of the society. The purpose of an article is to present the results of the research about the development of adults' autonomous English learning experience in blended learning environment. It is intended to analyse the development of autonomous learning approach towards its holistic comprehension in blended learning environment and present the results of the case study $(\mathrm{N}=50)$, realised by methods of the survey and SWOT analysis, about the process of transformation of adult learners' experience. Fractal of learning action based didactic model is theoretical and practical result of the research. It visualises systemic view of didactic categories of autonomous learning - learner's and mentor's learning action, learning environment - and makes the methodological base for pedagogical facilitation of the development of experience of autonomous English learning in blended learning environment in adult nonformal education.
\end{abstract}

Keywords: autonomous English learning experience, blended learning environment, transformation.

\section{Introduction}

Pedagogical phenomena of holistic education, development of integrated (Forbes, 2003; Martin, 2003) personality and the concept of learning environment (Dewey, 1966; Rousseau, 1979) have been the focus of attention of many authors in the past. New aspects to these phenomena are added by nowadays postmodern situation when paradigm shift in education is actualised by connectedness of human's action and the environment. Educational environment (Bell et al., 2002) is promoting the process of learner's cognition and developing of the whole person during his / her activity with the mentor for the development of English competence. Adult learners' involvement in the learning process of nonformal education, their interactivity in group and with ICT (information and communications technology) expands the learning environment and is connected with global goal of qualitative education: ensure inclusive and equitable quality education and promote lifelong learning opportunities for all (United Nations, 2015, 19).

D. Liegeniece (1999) distinguishes the concept of the learning environment: the structured environment, the developing environment, the environment of things those correspondents to educational, developmental and educative aim of education (Žogla, 2017). Structured environment complements it with the structure of time, interpersonal communication and organisational factors that is important for the development of learning to learn competence and experience of autonomous learning.

The developing learning environment supposes involving different learner's abilities in acquisition of the learning content for the development of personality as a whole. The development of learner autonomy using a postmodern and poststructural orientation is investigated by C. O'Leary (2018). She stresses participants' - "pluralist perspective" in constructing the reality of learning within their specific learning context, moving away from macro theories closer to practice and the possibility of change at a micro level.

Nowadays environment of things includes different ICT demanding digital skills and critical thinking. Technologically facilitated autonomous language learning (Benson, 2011) is the result of transformation of functions of technologies in pedagogy: from the subject of learning they have become a didactic mean for realisation of learning tasks, but the accessibility to the internet has promoted changes in the learning environment and expanded the possibilities of lifelong learning.

Nevertheless, results of special research of EC Eurobarometer 386 (European Commission, 2012) show insufficient adults' learning experience for participation in the learning process in technological age, but 
insufficient using of interactive learning possibilities, proposed by ICT, and using of blended environment in English learning reduces their participation in learning.

Blended learning as the qualitative conception stresses the thoughtful integration of classroom face-toface learning experiences with online learning experiences (Garrison, Kanuka, 2004, 96). In reorganisation of the instruction and learning dynamic based on new ICT transformed learning conditions the most significant changes in blended learning are connected with changes in learning experience from organised learning in the classroom environment to organised learning in virtual learning environment.

Nevertheless, the possibility to manage normative learning process and supervise the learning outcomes (Garrison, Kanuka, 2004) increases a contradiction between normative component of organised process of facilitation and free accessibility of external means of English learning. That forms pedagogical problem of the research: what kind of help is optimal for adult learners in nonformal education in order that blended environment of organised learning process (psychological, social and technological) promotes the development of their autonomous learning experience.

Using of ICT in the process of learning languages enriches the learning environment. Necessity of comprehension of influence and using of possibilities of the environment created by ICT should be taken in account when learner centred paradigm is realised from the point of view of complex sustainable development of the society supposing involvement learners into the development of own's personality.

It gives the opportunity to integrate learners' experience of organised and self-organised learning in blended learning environment of adult nonformal education as joining link between formal and informal learning. Common feature of these kinds of learning process is a fractal of learning action (Broks, 2000; Broks, et al., 2013). There are several concepts connected with autonomous learning that are not synonyms: self-directed learning, self-regulated learning, self-determined, self-organised learning. Theoretical analysis of the development of autonomous learning approach shows its development towards its holistic comprehension in blended learning environment that includes the concepts mentioned above.

Historically the concept of autonomous learning is introduced by C. Rogers (1967) and depends on philosophical principle of learner centred paradigm of education: freedom as one's choice and responsibility. As universal value, it corresponds to situation in which learners study entirely on their own; a set of skills which can be learned and applied in self-directed learning; an inborn capacity which is suppressed by institutional education; the exercise of learners' responsibility for their own learning; the right of learners to determine the direction of their own learning (Benson, Voller, 1997, 1).

M.S. Knowles (1970; 1975) outlines self-directed learning implements in nonformal education. Teaching process and learner's facilitation depends on adult learner's need to know, learner's self-concept and experience, readiness to learn and orientation to learning, motivation. The contract should be concluded between the learner and the learning institution.

Self-regulated learning (SRL) depends on teacher's managed autonomous learning where the learner becomes a subject of learning in the process of improving his / her learning skill. In this meaning the approach of SRL is used in English learning. Autonomy in foreign language learning is defined as ability to take charge about own's learning and the process that has to be acquired (Holec, 1981). As follows, the concept of autonomy moves the focus from teaching to learning where learning strategies (O'Malley, Chamot, 1990; Oxford, 1990, 2003) are important for improving language skills.

Self-determined learning in group is directed towards reaching own's learning goal that is also the goal of his / her life action (Rubene, 2003). The further development of autonomous learning is directed towards increasing interactivity in group aimed to coordinate the learning goal and facilitate each other in its reaching and involving learners in interactivity with technologies for the development of English competency.

English learning in virtual learning environment is motivated if autonomous learning develops to selforganised learning (SOL) in open virtual environment (Benson, Voller, 1997). SOL in this research is an organisational form of the learning process where self-determined learners cooperate and interact in group in virtual environment. The new quality of learning action is reached by self-organisation of participants during the learning process. Systemic changes lead to new learning community centred relationships between participants of the learning process. 
That changes a teacher's role because his / her authority is delegated to learners and to groups. Group autonomy is promoted because learners should consult with groupmates before asking the teacher (Jacobs, Power, Inn, 2002, 6).

P. Benson's (2007) review of developments in the philosophy of autonomy and the role of autonomy in global educational policy and reform shows that postmodern theory of autonomous personality depends upon a theory of narrative identity (Straub, Zielke, Werbik, 2005). From this perspective, autonomy is not grounded in substantive individual identities, but in identities that become individual through narratives involving self-reflection and self-thematization. It has value for work on the development of autonomy through long-term experiences of language learning (Benson, 2006).

The whole of the lesson is influenced by variety of learning possibilities that are not determined in time and place. That leads to accepting a fractal pattern of activity as the whole of the learning process. Fractal is a concept of practice introduced in systemology of education in Latvia by A. Brok (Broks, 2000; Broks, Jonāne, Vilks, 2013). Fractal is a repetitive pattern of action (Flower, 2014); a cycle of human's purposeful action (Broks, 2000); a problem-solving cycle for considered life: observing - thinking designing or planning - acting (Bawden, 2016).

Methodological base of using fractal approach in education is proposed by L. Jonāne (2009). She has produced the conceptual model - didactic fractal for organisation of the learning process for implementation the goal of education of natural sciences - the development of the competence oriented sustainable action.

A fractal of learning action identifies the learning action in any learning environment independently from the form of education and organisational form of the learning process. Open ICT based learning environment ensures inclusion of learning action, based in fractal structure of general action (investigation - consideration - action), in learning action of lifelong learning, learner's life action and general human action (Broks, 2000) in the context of sustainable development of society.

The aim of the study is to produce an appropriate pedagogical model for learners' involving in blended learning environment that makes easier for learner to transform from organised learning action to selforganised learning action, to evaluate and create own's learning environment for the development of autonomous learning experience.

\section{Methodology}

Several research questions were advanced for implementation of the study:

- What is the essence of autonomous English learning in postmodernism, what are indications of English learners' autonomous learning experience and the dynamic of its development in blended learning environment?

- What characteristics of mentor's action and personal characteristics are desirable for the teacher for the improving learner's learning experience in blended learning environment?

- How to facilitate a learner of nonformal education in evaluation of own's learning environment and its creating, and in transformation of learning action for the development of autonomous learning experience in blended learning environment?

After theoretical investigation and creating the questionnaire, the case study was done. Autonomous English acquisition readiness scale (AEARS) in blended learning environment was created on the base of results of the qualitative part of the research. It is a three level Likert-type scale that includes the level of learning environment, organisational forms of the learning process and learning methods exposed by metacognitive strategies (MCS). Its validity depends on comparing of theoretically selected and practically obtained criteria with the European language portfolio for adults (European Language Portfolio..., 2006).

Reliability of the AEARS is based on exploratory factor analysis of distinguished factors done for factorial analysis of the structure of the questionnaire and for selecting the main components in quantitative part of the research (Bojāre, Ignatjeva, 2014). Factorial analysis allowed to find the structure of four factors distinguishing four forms of organisation of the learning process based on the organisational approach of facilitated self-regulated learning, self-determined learning in group, self-directed learning in classroom learning environment and holistic English acquisition in virtual learning environment. Respondents have 
not distinguished separate structural elements in English learning in virtual learning environment. Summative dispersive percent, that could be explained by these factors, is $78,7 \%$.

The validity of Cronbach's Alpha, reflecting congruence of obtained indices, ranges from $0.932(\mathrm{~K})$ to 0.976 (V). Cronbach's Alpha coefficients and the coefficients of correlation the index with attributes characterises the methodological approaches that allow to reduce initially composed questionnaire with 51 items to 21 items. After that the amount of indicates in each attribute is three, but totally in the questionnaire - 126. Reduced questionnaire is used for organisation of the survey in the case study.

Sample of the case study $(\mathrm{N}=50)$ was completed by choosing the volunteers from the group of English learning programme of adult nonformal education. The case study is realised in three cycles with number of participants in the first cycle $(\mathrm{N} 1=46)$, thirty-two of them took part in the second cycle $(\mathrm{N} 2=32)$ and four their mentors took part in the third cycle $(\mathrm{N}=4)$ of the research.

Quantitative data for characteristic of the group depending on respondents' attitude towards proposed organisational forms of autonomous learning process and their connection with MCS were obtained by the survey in the first cycle of the case study. Participants of the group made SWOT (strong sides, weak sides, opportunities and threats) analysis of MCS in classroom and virtual learning environment for obtaining qualitative data during the second cycle of the case study.

SWOT analysis of using MCS in classroom and virtual learning environment was done for investigation of opportunities of facilitation of the learning to learn competence. Weak sides of MCS were excluded from SWOT analysis by factorial analysis done in the quantitative part of the research. Participants of the case study made SWOT analysis individually, in pairs and groups. Their mentors did the same in the third cycle of the case study.

\section{Results}

The results of the survey in the case study characterises the research group as L--++ in accordance to divergence of its attitude towards organisational forms of the learning process (figure 1) from average evaluation -3.45 points. The group includes characterises with the lowest evaluation of English acquisition in virtual learning environment and then average in the whole.

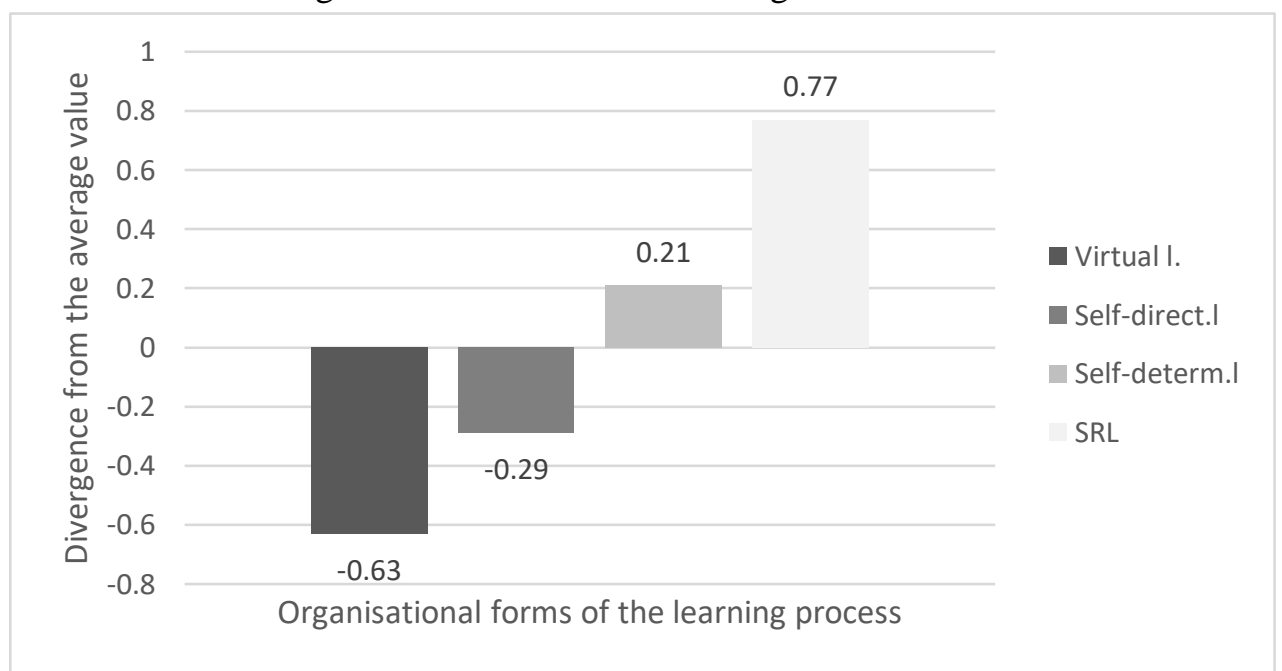

Figure 1. Group's L--++ attitude towards organisational forms of the learning process.

Where:

F_1 is K- self-regulated learning in the classroom;

F_2 is G- self-directed learning in the classroom;

F_3 is P- self-determined learning in the classroom;

F_456 is V-self-organised learning in virtual learning environment.

Group's L--++ attitude towards MCS is summarised in Table 1 where the highest evaluation is given for MCS of skills. It correspondents to traditional pedagogical approach and adults' experience of learning the foreign languages. 
Evaluation of MCS given by the participants of the case study shows to their mentor the actuality and hierarchy of learners' needs in reaching learning goal - English competence, for example, they need the tutoring in choosing methods / strategies for doing learning tasks.

Results of the SWOT analysis of MCS allows to conclude that pedagogically and technologically traditional self-regulated acquisition of English skills is facilitated in English programmes of adult nonformal education.

Table 1

The content of the metacognitive strategies and their evaluation by group L--++

\begin{tabular}{|c|c|c|}
\hline MCS & Content of MCS & Values \\
\hline Skills & Working with learning materials; acquisition of listening skill; translation of texts & 3,58 \\
\hline Knowledge & Reading of texts; answering questions about the text; acquainted grammar rules & 3,56 \\
\hline Planning & $\begin{array}{l}\text { Corrections of learning action for reaching the learning goal; taking responsibility about } \\
\text { own's learning process; positive emotions connected with learning the English language }\end{array}$ & 3,47 \\
\hline Organisational & $\begin{array}{l}\text { Choice of the learning topics; choice of the learning materials; dividing of the } \\
\text { learning content }\end{array}$ & 3,45 \\
\hline Evaluation & $\begin{array}{l}\text { Determination of the criteria of the quality of the learning result; evaluation of the } \\
\text { learning result; evaluation of quality of the learning process }\end{array}$ & 3,42 \\
\hline Development & Writing a letter; writing essays; general investigation of the topic & 3,37 \\
\hline Participation & $\begin{array}{l}\text { The choice of strategies and methods for doing the tasks; making tables about } \\
\text { acquainted topics, grammar rules; making mind maps and schemes about } \\
\text { acquainted topics, grammar rules }\end{array}$ & 3,32 \\
\hline
\end{tabular}

Pedagogical function of investigation of attitude of participants of English programmes of adult nonformal education is self-reflection about own's learning; comprehension of learning opportunities for improving the quality of choice and removing threats that inconvenience to realise these opportunities.

Environment of ICT and social environment has already influenced learners' attitude so learner's action should be pedagogically transformed by adapting mentor's comprehension to learner's comprehension and by widening of learner's comprehension with comprehension of MCS in the environment.

SWOT analysis of MCS in classroom and virtual learning environment shows common and different in learner's and mentor's evaluation and substantiates the content of facilitation of MCS.

Results of SWOT analysis show that action in virtual learning environment generally is connected with individual learning. Realised SWOT analysis helps learners and their mentors to conscious changes in learning environment and stimulates to change the learning action. Important direction of transformation of the learning action is transition of levels of interactivity in the classroom to virtual learning environment, integration of organised and self-organised learning process in blended learning environment, promoting of learner's participation in learning process. Changes in learning environment creates necessity to widen learning facilitation from traditional pedagogical facilitation of acquisition of learning content by using ICT, to promoting learner's participation for the development of their English competence and learning to learn competence in blended learning environment.

The research gives mentor the comprehension that changes in learning environment create systemic changes in learning process and in needs of facilitation of learning. Facilitation of learning should be adopted to learners' new needs. Results of SWOT analysis of MCS show the directions of help for the development of learner's experience of holistic autonomous English learning in blended learning environment:

- promoting individual and group's responsibility, planning of learning goal / result, maintaining of interest;

- involving learners in creating of favourable relationship and learning environment, purposeful learning process, social cooperation and interactivity with ICT for the development of English competence and its practical use in the learning process;

- developing skills of using ICT for promoting using of internet resources for choosing of learning content and ensuring of interactivity in virtual learning environment;

- promoting the development of critical thinking in the choice of the learning content, involving learners in structuration of learning content and time management; 
- involving learners in exchange of views about learning process and criteria of the quality of the result, in evaluation of learning process and result, in self-control and analysis of the learning result;

- promoting the use of printed and digital learning resources for investigation of learning topics from different perspectives and for doing individualised and specific creative tasks given to particular learner;

- increasing learners' individual / group's contribution in learning process by giving them opportunity to choose a strategy for doing the task; structuration of the learning content, making dialogues.

Experience of autonomous learning is precondition, the goal of the development, resource and outcome of learning necessary for self-involvement in lifelong learning. Changes in learning environment create transformation in learners' attitude towards learning that, in its turn, actualises transformation of the learning action. Self-organised learning, collaboration, participation and self-control in blended learning environment are the features of the experience of holistic autonomous English learning. Learners' experience of holistic autonomous English learning in blended learning environment and active participation in learning process is the base of changes for sustainable development of society where a mentor fulfils a role of the agent of changes.

The mentor needs English competence, using of ICT / digital competence, competence of pedagogical facilitation and promoting of collaboration for implementation of the fractal of the learning action.

Iterations of interconnected teacher's and learner's interaction, based on paradigm shift from teaching to learning and underlying on principle of fractal action, form the complex learning process in the learning environment. Teacher's action with adult learners acquires such characteristics and the character of help that are more relate to mentor's action and role. The new quality of teacher's action forms transition of teacher's action from working in the programme with learners to mentor's help to realise them the programme.

A conception of the research for promotion adult learners' experience of autonomous English learning in blended learning environment is based on integration of learners' experience of organised learning and self-organised learning in blended learning environment by connection of learner's and mentor's action in blended learning environment for improving learning process in adult nonformal education.

Results of the research allow to create simplified didactic model for nonformal education - the fractal of the learning action. It includes conceptual and methodological aspect of holistic autonomous English learning in blended learning environment. Learner's and mentor's action is connected in the environment. The experience of autonomous learning develops by transformation of learning action from organised learning in the classroom to self-organised learning action in virtual learning environment.

The learner starts to evaluate own's learning action and learning environment, starts to create technologically mediated learning environment. Virtual learning environment increases transformation of unknown content to known content with changes in learner's attitude towards learning process and creates new quality level of autonomous learning - holistic autonomous English learning in blended learning environment integrating forms of autonomous learning mentioned above. 


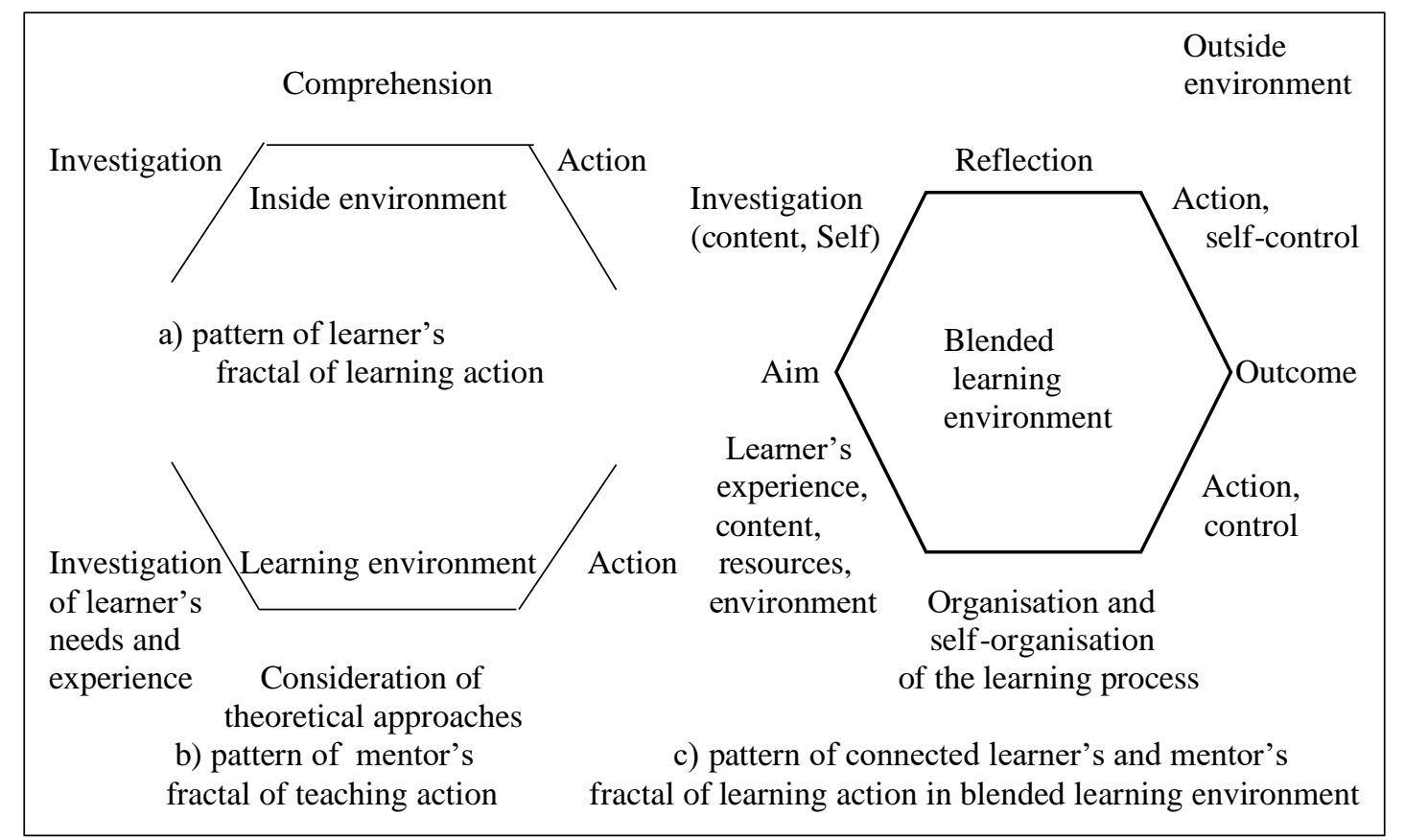

Figure 2. Patterns of learner's and mentor's learning action in the learning environment.

Patterns $a$ and $b$ are made by specifying Brok's general pattern (Broks, Jonāne, Vilks, 2013, 5). The pattern c is author's produced by joining fractals of learner's and mentor's learning action in blended learning environment.

The influence of changes in the learning environment on the process of learning is investigated in this research. Changes create a complex system where linear development of the experience of autonomous English learning for improving learner's English competence by self-directed, self-regulated, selfdetermined learning and self-organised learning, emerged of autonomous learning, transforms to nonlinear / integrated development of experience of holistic autonomous English learning in blended learning environment. The results of the research allow to connect fractals of learner's and mentor's learning action in the learning environment (Figure 2) with double feedback loop: (1) between management / self-management of cognitive and metacognitive process and the skill of using learning resources and learning environment; (2) between learner's acquired experience of autonomous English learning and the experience of autonomous English learning that should be acquired with transformation of his / her attitude towards organised and self-organised learning process as a middle result in the direction towards holistic autonomous English learning process in blended learning environment (Figure 3). Connection of the structure of pedagogical process (Žogla, 2017) with the fractal structure of scientific investigation and general human action (Broks, 2000) is shown in Table 2.

Table 2

\section{Connection of the structure of pedagogical process (Žogla, 2017) and the fractal of general} human action (Broks, 2000)

\begin{tabular}{|c|c|c|}
\hline $\begin{array}{l}\text { Pedagogical process / } \\
\text { fractal of action }\end{array}$ & $\begin{array}{l}\text { External component of } \\
\text { teacher's action }\end{array}$ & Internal component of learner's action \\
\hline Investigation / cognition & $\begin{array}{l}\text { Standards, aims, objectives, } \\
\text { incentives, teacher's experience }\end{array}$ & $\begin{array}{l}\text { Learning identification, reasoning, } \\
\text { motivation, learner's experience and level of } \\
\text { autonomy }\end{array}$ \\
\hline Theory / consideration & $\begin{array}{l}\text { Suggested process design, } \\
\text { teaching structure }\end{array}$ & Learner's acceptance of process design \\
\hline Action & $\begin{array}{l}\text { Content, subject-matter, goals } \\
\text { (academic outcomes), } \\
\text { reflection, evaluation }\end{array}$ & $\begin{array}{l}\text { Learner's tools, learning structures, learner's } \\
\text { personal achievements, self-assessment, } \\
\text { self-evaluation }\end{array}$ \\
\hline $\begin{array}{l}\text { Next cycle of investigation } \\
\text { - consideration - action }\end{array}$ & \multicolumn{2}{|c|}{ To further aims and objectives } \\
\hline
\end{tabular}


Conditions of connection of didactic model and the fractal of learning action is implementing of complex learning aim that is shown by learning outcome - acquainted experience of holistic autonomous English learning in blended learning environment. It integrates implementation of educational, developmental and educative aims: the experience of acquainted learning content - competence of English, experience of changes in the attitude towards learning process - competence of learning to learn and the experience of learner's autonomy as the value - holistic autonomous learning in blended learning environment.

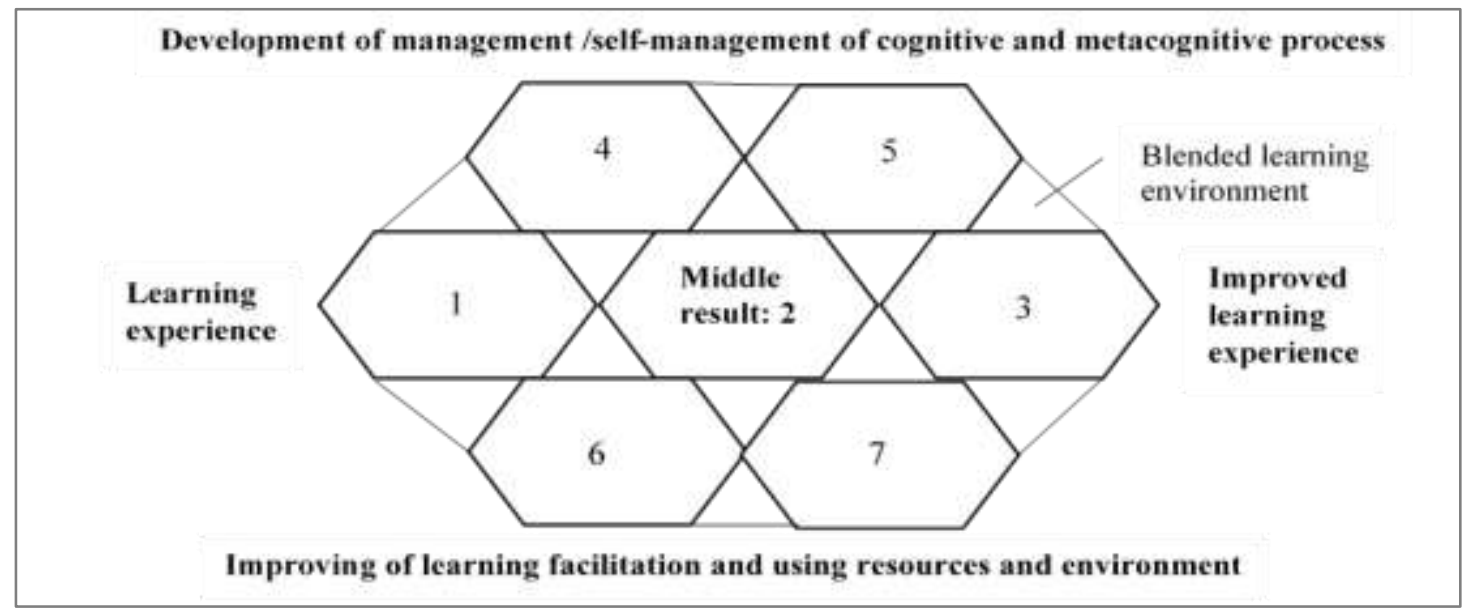

Figure 3. Pattern of the fractal of learning action in integrated organised and self-organised learning process in blended learning environment (author's produced).

Where 1 - goal, content, organisation of the process; 2 - change of the attitude; 3 - self-organisation of learning process, result; 4 - cognitive strategies of learning; 5 - meta-cognitive strategies; 6 - pedagogical facilitation; 7 - choice of resources, using of environment.

The model of holistic autonomous English learning in blended learning environment - the fractal of learning action visualises interconnected learner's and mentor's action in blended learning environment. The experience of autonomous learning develops by transformation of learning action according to transformation of the attitude.

The pattern of the learning action reflects essential didactic categories of educational / English learning action in conceptual aspect and in the aspect of organised and self-organized learning process. In conceptual aspect mentor is conscious about (a) the aim of holistic education - the development of integrated personality, (b) context - sustainable development of society and (c) the content of pedagogical facilitation and process for moving towards the learning goal: learner's action of learning, pedagogical facilitation and learning result.

The development of the management / self-management of cognitive and metacognitive processes and the development of skill of using learning environment and resources in social and ICT environment is stressed in organisation of the learning process. Transformation of the experience of autonomous learning to holistic autonomous English learning in blended learning environment happens by integration of learner's self-directed, self-regulated and self-determined learning experience in self-organised learning experience and differentiation of learner's attitude towards metacognitive strategies - MCS.

Metacognitive strategies of action are directed towards already known: the broadening of knowledge / collaboration, improving skills, development and broadening of the experience (Boghian, 2016; Clegg, 2015) by synthesis of metacognitive, cognitive, social and affective learning strategies in MCS of action. Mentor's facilitation changes during the development of learner's experience. During pedagogical facilitation the mentor is planning and organising the learning environment for purposeful, transformative and holistic learning process where the learner step by step is able to reach his / her learning goal - English competence and learning to learn competence.

By dividing of the pattern of the learning action based on MCS, the content of MCS for connection of learner's and mentor's learning action in goals, motives, choice of means / resources, evaluation and self-evaluation of the results is exposed in the case study. The content of facilitation of the MCS follows from the results of SWOT analysis of MCS in classroom and virtual learning environment. 
Mentor's facilitation should be adapted to learner's necessities of learning facilitation in blended learning environment. The result of nonlinear development of the experience is reached in the process of multiple iterations of learning episodes. The feedback occurs at learner's and mentor's, learner's and group's, learner's and ICT levels of interactivity according to organisational form of the learning process in blended learning environment.

\section{Conclusions}

- In the process of holistic autonomous English learning in blended learning environment two integrated actions - learner's learning and mentor's help - are coordinated by didactic model that changes the learning process by transformation of these actions from organised help and organised independent learning action to self-organised learning and mentor's help, but the fractal structure of learner's learning and mentor's help determines including of these actions in life action and general human action in the context of sustainable development.

- The process of holistic autonomous English learning in blended learning environment promotes transformation of linear development of learner's experience of autonomous learning in nonlinear / integrated development of learner's experience of autonomous learning that strengthens essential qualities of autonomous learning in learner's experience - responsibility, cooperation, ability and skill to use metacognitive strategies in interaction with social and ICT environment in blended classroom and virtual learning environment what simplified didactic model - the fractal of the learning action - helps to organise in nonformal education.

- In holistic autonomous English learning in blended learning environment the learner persuades in the importance of own's participation in the learning process and is active its participant that allows to decrease teacher's facilitation in improving of the skill of self-management of cognitive and metacognitive process and using learning resources and learning environment. Working with adult learners saves some teacher's characteristics (individual approach and facilitation of participation, skill of using academic knowledge and ICT, research skill, the competence of organisation of the learning process), but the qualities should be borrowed from the mentor are tolerance and openness to learner's learning experience, common responsibility and mutual loyalty; the experience of learning other foreign languages and still to use them in real situations; ability to make horizontal relationships with learners to promote setting and reaching learning goal common for group; the skill to organise learning process in blended learning environment according to structure of general action: investigation - consideration - action.

\section{Bibliography}

1. Bawden R. (2016). An Atlas of Conceptual Maps: Linking Cognitive Processing with learning and the development of identity - making sense of our thinking. Retrieved from

https://www.education.sa.gov.au/sites/default/files/an_atlas_of_conceptual_maps.pdf?v=1457328077

2. Bell P.A., Greene T.C., Fisher J.D., Baum A.S. (2002). Environmental Psychology (5 ${ }^{\text {th }}$ ed.). Wadsworth: Thomson.

3. Benson P. (2007). Autonomy in Language Teaching and Learning. Language Teaching, 40, 21-40. doi: $10.1017 / \mathrm{S} 0261444806003958$

4. Benson P. (2011). Teaching and Researching: Autonomy in Language Learning (2 ${ }^{\text {nd }}$ ed.). London, New York: Routledge Taylor, Francis Group. doi: 10.4324/9781315833767

5. Benson P., Voller P. (Eds.). (1997). Autonomy and Independence in Language Learning. London: Longman.

6. Boghian I. (2016). Metacognitive Learning Strategies in Teaching English as a Foreign Language. Journal of Innovation in Psychology, Education and Didactics, 20(1), 53-62.

7. Bojāre I., Ignatjeva S. (2014). Autonomous English Acquisition in Blended e-studies for Adults for Sustainable Development: Quantitative research. In V. Dislere (Ed.), The Proceedings of the International Scientific Conference Rural Environment. Education. Personality (REEP), 7. Jelgava: LLU, 42-49. Retrieved from https://llufb.llu.lv/conference/REEP/2014/Latvia-Univ-Agricult-REEP-2014proceedings-42-49.pdf

8. Broks A. (2000). Izglìtības sistemologija [Systemology of Education]. Rīga: RaKa. (in Latvian)

9. Broks A., Jonāne L., Vilks I. Salītis A., Krons A., Paulins P., Harja J., Voitkāns A. (2013). Vispārizglītojošā fizika profesionālajās vidusskolās: metodisks materiāls fizikas skolotājiem [Physics in Comprehensive Secondary 
Schools: Methodological Materials for Teachers of Physics]. Rīga: LU akadēmiskais apgāds. Retrieved from http://blogi.lu.lv/broks/files/2012/11/Broks-u.c.-VFPV2013.pdf (in Latvian)

10. Clegg J. (2015). Metacognition: An Overview of its Uses in Language-learning. Retrieved from https://www.slideshare.net/hamizahosman $1 /$ j-cleggmetacognitionanovwerviewofitsusesinlanguagelearning

11. Dewey J. (1966). Democracy and Education: An Introduction to the Philosophy of Education. New York: The Free Press; London: Collier Macmillan.

12. European Commission. (2012). Europeans and Their Languages. Special Eurobarometer 386. Report. Retrieved from http://ec.europa.eu/commfrontoffice/publicopinion/archives/ebs/ebs_386_en.pdf

13. European Language Portfolio for Adults. (2006). Rīga: Public Service Language Centre. Retrieved from https://valoda.lv/wp-content/uploads/docs/Projekti/LV_mat_evp_pieaug.pdf

14. Flower E. (2014). Fractals in Forex Trading. Retrieved from http://www.onestepremoved.com/fractalsforex-trading/

15. Forbes S.H. (2003). Holistic Education: An Analysis of its Ideas and Nature. Brandon, VT.: Foundation for Educational Renewal.

16. Garrison D.R., Kanuka H. (2004). Blended Learning: Uncovering its Transformative Potential in Higher Education. Internet and Higher Education, 7(2), 95-105. doi: 10.1016/j.iheduc.2004.02.001

17. Holec H. (1981). Autonomy and Foreign Language Learning. Oxford: Pergamon Press.

18. Jacobs G.M., Power M.A., Inn L.W. (2002). The Teacher's Sourcebook for Cooperative Learning: Practical Techniques, Basic Principles, and Frequently Asked Questions. Thousand Oaks, California: Corwin Press, Inc.

19. Jonāne L. (2009). Kontekstuālās pieejas īstenošana dabaszin̄̄bu kompetences pilnveidei vispārējā vidējā izglītībā: promocijas darba kopsavilkums [Implementing of Contextual Approach for Improving of Competence in Sciences in Comprehensive Secondary Schools]. Daugavpils: Daugavpils Universitātes Akadēmiskais apgāds „Saule”. (in Latvian)

20. Knowles M.S. (1970). Modern Practice of Adult Education: Andragogy Versus Pedagogy. Chicago: Association Press.

21. Knowles M.S. (1975). Self-directed Learning: A Guide for Learners and Teachers. Chicago: Association Press.

22. Lieǵeniece D. (1999). Kopveseluma pieeja audzināšanā [Holistic Approach to Upbringing]. Rīga: RaKa. (in Latvian)

23. Martin R.A. (2003). Teachers as Learners: Case Study of an Action Research Program within Holistic Education (Doctoral dissertation, Iowa State University, Ames, Iowa, US) Retrieved from https://lib.dr.iastate.edu/cgi/viewcontent.cgi?article=1603\&context=rtd

24. O'Leary C. (2018). Postmodernism as a Theoretical Framework for Learner Autonomy Research. SiSAL Journal, 9(3), 342-370. Retrieved from https://sisaljournal.org/archives/sep18/oleary/

25. O'Malley J.M., Chamot A.U. (1990). Learning Strategies in Second Language Acquisition. Cambridge, U.K.: Cambridge University Press.

26. Oxford R.L. (1990). Language Learning Strategies: What every Teacher should Know. New York: Newbury House. Retrieved from https://escholarship.org/content/qt1446j36q/qt1446j36q.pdf

27. Oxford R.L. (2003). Language Learning Styles and Strategies: An Overview. Learning Styles and Strategies. /Oxford: GALA. Retrieved from http://web.ntpu.edu.tw/ language/workshop/read2.pdf

28. Rogers C. (1967). The Facilitation of Significant Learning. In L. Siegel (Ed.), Some Contemporary Viewpoint of Instruction. San Francisco: Chandler Publishing Co.

29. Rousseau J.J. (1979). Emile, or On Education, introduction, translation and notes by Allan Bloom. New York: Basic Books.

30. Rubene Z. (2003). Jauniešu kritiskās domāšanas izpēte studiju procesā universitātē [Research of critical thinking of young people in the study process at university]. (Doctoral Thesis, University of Latvia). Retrieved from https://dspace.lu.lv/dspace/handle/7/540 (in Latvian)

31. Straub J., Zielke B., Werbik H. (2005). Autonomy, Narrative Identity, and their Critics: A Reply to Some Provocations of Postmodern Accounts in Psychology. In W. Greve, K. Rothermund, D. Wentura (Eds.), The Adaptive Self: Personal Continuity and Intentional Self-development. Cambridge, MA: Hogrefer \& Huber, 323-350.

32. United Nations. (2015). Transforming our World: the 2030 Agenda for Sustainable Development. A/RES/70/1. Retrieved from https://www.unfpa.org/resources/transforming-our-world-2030-agendasustainable-development

33. Žogla I. (2017). Pedagogy and Educational Sciences: Competing Traditions in the Study of Education in Latvia. In G. Whitty, J. Furlong (Eds.). Knowledge and the Study of Education: an International Exploration. Oxford: Symposium Books. / Oxford Studies in Comparative Education, 27(1), 101-122. 